\title{
Affiliated Identities as a Design Tool for a Jewish Literature Course
}

My book Affiliated Identities in Jewish American Literature suggests a framework for understanding writers' Jewish identity. ${ }^{1}$ The basic argument of Affiliated Identities is that Jewish writers often build, shape, and maintain their public identities as Jews by way of exhibiting ties with other Jewish writers. Much of this networking takes place as part of works of literature. I believe that this framework is highly pertinent for the pedagogy of Jewish literature in higher education, especially Jewish literature as a transnational multi-lingual phenomenon. In this short paper, I will suggest that instructors can use this idea as tool for designing courses or segments of courses. Thus, the teaching of Jewish literature can be planned around a certain author's network of literary affiliations. At least in the American case, which was my focus, these ties are often international rather than restricted to a national canon (or even to a linguistic one). Thus, designing courses around the concept of Jewish literary networking will also establish Jewish literature's multi-lingual and border-crossing nature in a way that is more organic than simply deploying a survey of "the best of" Jewish writing in a plethora of languages. Furthermore, Jewish writers also connect themselves to non-Jewish writers. Following these links can help show how Jewish writing is embedded in non-Jewish national and linguistic traditions.

Let me give two American examples for what I mean. The idea of the course is to have an author or a text as the central node of a literary network and then explore (or let students explore) the other texts or authors that are once or twice removed from this central node. In the first example the center is an author, while in the second example it is a novel that works to connect its authors to other writers.

Emma Lazarus is often credited as the founding mother of Jewish American literature. She is hardly a household name, but three lines she wrote are some of the most well-known lines in American poetry. They come from "The New Colossus," a poem dedicated to The Statue of Liberty: "Give me your tired, your poor,/ Your huddled masses yearning to breathe free,/The wretched refuse of your teeming shore" (Lazarus 2005, 48-9). Lazarus comes from a German Jewish and Sephardi heritage. Both sides of her family have lived in America before she was born and were largely assimilated. At the beginning of her career she

1 Bloomsbury Academic, 2020.

Ә OpenAccess. ( 2020 David Hadar, published by De Gruyter. (cc) BY-NC-ND This work is licensed under the Creative Commons Attribution-NonCommercial-NoDerivatives 4.0 License. 
was deeply influenced by the American philosopher-poet Ralph Waldo Emerson and corresponded with him. This connection is an opportunity to show a Jewish writer embedding herself within a national tradition - Emerson being one of the central figures in the American canon (See Levinson 2008, 18ff.). Later in her life, partly due to the anti-Semitic violence in Russia and the wave of poor Jewish immigrants that hit American shores in the early 1880s, she reconnected to her Jewish identity and supported relief efforts and an early version of Zionism. This change was also marked in her poetry. One important poem for this shift is "In the Jewish Synagogue at Newport." This poem is clearly an answer to Henry Wadsworth Longfellow's well known poem "The Jewish Cemetery at Newport." However, whereas Longfellow puts Jews squarely as a dead nation that belongs to the past, Lazarus shows that Jews are part of the present and future of America (Wolosky 1996, 117). This is an example of a Jewish writer rewriting a non-Jewish writer in a way that defangs some anti-Semitic notions. In this case, Lazarus deflects the idea that Jews belong to the past and should remain outside of the modern nation.

Lazarus also engages with Jewish writers. Her association with Jewish themes began with a translation of "Donna Clara," a poem about Jewish history written by Heinrich Heine, the Jewish German poet, two years before his conversion to Christianity. Lazarus not only translated the poem Heine wrote but also used a letter detailing two poems that were to complete a trilogy, to write her own, thus "entering modern Jewish literature via Heine's abandoned project" (Levinson 2008, 28). Lazarus forms her Jewish identity in correlation with rewriting Heine, who despite his conversion is usually considered important for Jewish literature.

Furthermore, Lazarus could also provide examples of how Jewish writers utilize biblical texts and connections to biblical authors in particularly Jewish ways. In “The New Ezekiel," Lazarus associates herself with a biblical prophet, one who is said to have written the book that caries his name. Ezekiel is thus also a figure of literary strength. The poem opens: "What, can these dead bones live, whose sap is dried/ By twenty scorching centuries of wrong?” bringing to mind Ezekiel's Vision of the Valley of Dry Bones (Ch. 37), an image that functions as a national allegory for the return of the exiled to the Land of Israel. The line also places us at a certain moment in history, "twenty scorching centuries" placing the speaker of the poem at least two-thousand years after the original Ezekiel and close to the historical Emma Lazarus. The second stanza promises: "I ope your graves, my people, saith the Lord/ And I shall place you living in your land" (Lazarus 2005, 85). This poem offers renewal of prophecy along with the renewal of Israel. It thus renders the poet as a new literary prophet, specifically a new Ezekiel. In writing this poem of national revival, Lazarus places herself in 
Ezekiel's sandals, creating a literary affiliation that sustains her role as a Jewish writer and one of prophet-like importance and resonance. Scholars also found biblical resonance in "The New Colossus." Daniel Marom argued that the Statue is the biblical matriarch Rachel, while Shira Wolosky identifies the Statue with Deborah of the Book of Judges (Marom 2000; Wolosky 1996). The association with Deborah is especially significant for our purposes because Deborah was a prophet and a poet, producing the victory hymn known as "The Song of Deborah” (Judges 5:2-31).

"The New Colossus" offers an opportunity for showing how others connect to the author under discussion (or at least her best known texts). The lines inscribed on the Statue of Liberty's pedestal have become a motto that the emblemized the United States' acceptance of immigrants, especially Jewish immigrants fleeing European anti-Semitism. As such it was a target of various kinds of citations and revisions. For example rock singer Lou Reed protest song "Dirty Blvd." includes a line that suggests that "The Statue of Bigotry" says she will "piss on" the huddled masses and then "club 'em to death" (1989). More recently, Donald Trump's adviser Stephen Miller downplayed the poem in a press conference as part of defending draconic immigration policies. This downplaying of a central American symbol was received with much chagrin on many quarters. Both Reed and Miller are Jewish - what my readers do with this fact is up to them. You could certainly challenge students to find other moments when "The New Colossus" is referenced in literary, popular culture, or political texts.

Another path is to focus on a certain text that does an extensive job of affiliating its author with other writers. ${ }^{2}$ Philip Roth's The Ghost Writer is a good example. In this short novel (and I think it is important to choose a relatively short text in this kind of course as to leave time for other texts) a young writer named Nathan Zuckerman visits a more experienced author E. I. Lonoff in his secluded New England home. Lonoff is easily associated with Bernard Malamud, but has also reminded some readers of I. B. Singer. Much of the first part is dedicated to discussing other writers, fictional and real, most of them Jewish. The main fictional writer they talk about is the hugely successful, somewhat pompous Felix Abravanel, who may lead to reading Norman Mailer and Saul Bellow. Zuckerman describes both Lonoff and Abravanel as related, thematically and stylistically to the Russian-Jewish Isaac Babel: "It's as though, as I see it, you are Babel's American cousin - and Felix Abravanel is the other" (Roth 1995, 47). Later

2 The inspiration for a course that orbits around one relatively short text comes from a wonderful graduate seminar I took with Prof. Shuli Barzilai at the Hebrew University - the central text was Freud's Wolf Man case history. 
on in the novel, much attention is given to a story by Henry James, so students can be reminded that Jewish writers have association with non-Jewish ones as well.

However, the most radical association created by the novel is with the person it describes as the most “famous” Jewish writer: Anne Frank (Roth 1995, 152). In one chapter of the novel, Zuckerman imagined that Anne Frank survived the Holocaust and is now living under a false name in the US, carrying out an affair with Lonoff. She cannot assume her true identity because she believes that the value of her diary would evaporate if the world knew she was alive. Later on, Zuckerman, who has been accused of Jewish self-hatred because of a story he is about to publish, imagines marrying Anne Frank as a kind of protection against such accusations. The Anne Frank connection should lead the class to read the Dairy as a nonfictional literary text. You could also examine its fascinating reception and adaptation history (see Spargo 2001). Thus, in this one novel, readers are sent to Russian, Yiddish, Dutch, and American texts, many of which but not all of which are Jewish.

I gave examples from American authors, but my readers may choose other starting points. A scholar of Polish literature might begin with Bruno Schulz, the short story writer and painter, who was murdered by a Nazi officer. One may explore Schulz's connection with Kafka and earlier Polish or Yiddish writers, but continue to the various Eastern European, American, and Israeli engagements with his literary legacy and tragic death. ${ }^{3}$ Other likely starting points from a variety of literatures could be King David as the Psalmist, Rabbi Yehuda HaLevi, Heine, Sholem Aleichem, Kafka, Anne Frank, or Yoram Kanyok (though, his best most networked novel, The Last Jew, is probably too long for this purpose). My readers would surely have their own candidates based on their own field and personal preferences.

Affiliated identities could be a covert principle behind the course's design at first. You could set up a course about Jewish poetry, but make sure that many of the writers Lazarus is connected to appear. Let students slowly discover the connections. Perhaps they will find some connections that you did not know about. Conversely, you can make affiliations, canon building, or intertextuality the main theme of the course. A novel like The Ghost Writer, where characters are preoccupied with these themes, is a perfect candidate for such an explicit concentration on how Jewish authors and texts are tied together. For the more direct approach add your favorite theoreticians of intertextuality: Bakhtin, Kristeva, and Harold Bloom come to mind.

3 For some of the American and Israeli engagements see Budick 2015, 127-145. 
Unfortunately, I have never deployed this approach as principle behind a whole course. However, I did have the chance to utilize this approach in sections of a Jewish American Literature course I taught to MA students at the John F. Kennedy Institute for North American Studies, Free University Berlin. This was a group of German and international students with a strong grasp of American culture, but (with some exceptions) little knowledge about Judaism or Jewish literature (American or otherwise). I deployed the affiliated identities approach on several occasions. I let students compare Lazarus's and Longfellow's Newport poems and made sure to connect The Ghost Writer to Bellow and Malamud, which they already read. To introduce a new example, I assigned Singer's "Gimpel, The Fool" (translated by Bellow); on the same week I assigned "Envy, or Yiddish in America" by Cynthia Ozick, a story that engages with Singer's success in creating a name for himself outside of Yiddish circles as well as the failure of most other Yiddish writers to do the same. Thus, even though the focus of the course was squarely on English language texts, we could not ignore a Yiddish context for Jewish literature. ${ }^{4}$

To conclude, it has often been argued that professors should narrow the gap between our teaching and our research. This paper offered an example how my research shapes the way I think about course design and individual lesson plans. I do not presume that many of my readers will now hurry to plan their next semester in accordance with the suggestions here. I do want to ask you to examine your own research and look for the places that show Jewish literature at its most international, trans-lingual, and intertextual, along with the places where your texts connect to Hebrew, Yiddish, Ladino, Jewish-Arabic and similar Jewish linguistic traditions. These angles from which you do your research might hold the keys for disseminating Jewish literature, broadly defined, in whichever tradition you teach and to whatever kind of students you have.

\section{Bibliography}

Budick, Emily Miller. The Subject of Holocaust Fiction. Bloomington: Indiana UP, 2015. Lazarus, Emma. Selected Poems. Ed. John Hollander. New York: The Library of America, 2005. Levinson, Julian. Exiles on Main Street: Jewish American Writers and American Literary Culture. Bloomington: Indiana UP, 2008.

4 Students also had an earful of some Modern Hebrew when my partner called me in the middle of class with a child related emergency. Everything's fine now. 
Marom, Daniel. "Who Is the 'Mother of Exiles'? An Inquiry into Jewish Aspects of Emma Lazarus's “The New Colossus.” Prooftexts 20.3 (Sept. 2000): 231-61. Project MUSE, doi:10.1353/ptx.2000.0020.

Reed, Lou. "Dirty Blvd.” New York. New York: Sire Records, 1989.

Roth, Philip. The Ghost Writer. New York: Vintage, 1995.

Spargo, R. Clifton. "To Invent as Presumptuously as Real Life: Parody and the Cultural Memory of Anne Frank in Roth's 'The Ghost Writer.”' Representations 76 (Autumn 2001): 88-119.

Wolosky, Shira. "An American-Jewish Typology: Emma Lazarus and the Figure of Christ." Prooftexts 16.2 (1996): 113-125. 